\title{
Effects of Phragmites australis growth on nitrogen retention in a temporal stream
}

\author{
María Isabel Arce*, Rosa Gómez, María del Rosario Vidal-Abarca and María Luisa Suárez \\ Department of Ecology and Hydrology, Faculty of Biology, University of Murcia, Campus de Espinardo, \\ 30100, Murcia. Spain.
}

* Corresponding author: marisarce@um.es

Received: 6/12/08

Accepted: 5/5/09

\begin{abstract}
Effects of Phragmites australis growth on nitrogen retention in a temporal stream

In recent years in Southeast Spain with the increase in irrigated land surface, there has been a massive growth number of Phragmites australis populations which ended up invading completely the intermittent streams (ramblas) and the shallow water channels in general. This situation brings forth the physical transformation of the channels, thus modifying many characteristics implicated in the biotic and abiotic processes involved in nitrogen retention. In this study, we tested the hypothesis that the channel invasion by Phragmites australis negatively affects nitrogen retention. Therefore, we compared the retention rates $(\% \mathrm{R})$ of $\mathrm{NO}_{3}^{-}-\mathrm{N}$ and $\mathrm{NH}_{4}^{+}-\mathrm{N}$ in different subreaches of the same temporal stream: a unvegetated subreach $\left(238 \mathrm{~m}^{2}\right)$, and two vegetated subreaches that differed in surface areas $\left(480 \mathrm{~m}^{2}\right.$ and $\left.910 \mathrm{~m}^{2}\right)$. The results showed that the retention efficiency $(\% \mathrm{R})$ for both solutes were higher in the unvegetated subreach. Although there are no conclusive results, it seems that the differences were more important outside the vegetated period of the helophytes, while during the spring-summer period an increase of the retention rates in the vegetated subreaches could occur. In the same way, the capacity of the subreaches for $\mathrm{N}$-nitrate retention, showed a clear dependency of the nitrogen inputs, decreasing as the nitrogen load increases. However, the unvegetated subreach showed a greater load capacity than the vegetated subreach with larger surface, and this one, greater than the vegetated subreach with the smaller surface. This study reveals that channel invasion by Phragmites australis, a generalized phenomenon in many parts of the world, not only can bring about changes in the structure of the vegetation and the fauna in the streams, but can also affect its function, and especially a key process involved in water quality, such as nitrogen elimination.
\end{abstract}

Key words: Nitrogen retention, ramblas, intermittent streams, Phragmites australis, invasion.

\section{RESUMEN}

\section{Efecto del crecimiento de Phragmites australis en la retención de nitrógeno en un río intermitente}

En los últimos años, en el SE ibérico con el incremento de la superficie de regadío, se ha producido un crecimiento masivo de las poblaciones de Phragmites australis que terminan invadiendo por completo las ramblas y en general los cauces de aguas superficiales. Esta situación lleva consigo la transformación física de los cauces, modificando muchas características implicadas en los procesos bióticos y abióticos de retención de $N$. En este estudio testamos la hipótesis de que la ocupación de los cauces por Phragmites australis afecta negativamente a la retención de N. Así comparamos las tasas de retención (\%R) de $\mathrm{N}-\mathrm{NO}_{3}^{-}$y $\mathrm{N}-\mathrm{NH}_{4}^{+}$en diferentes subtramos de una misma rambla: un subtramo no vegetado $\left(238 \mathrm{~m}^{2}\right)$ y dos subtramos vegetados que diferían en superficie $\left(480 \mathrm{~m}^{2}\right.$ y $\left.910 \mathrm{~m}^{2}\right)$. Los resultados demostraron que las eficacias de retención (\%R) para ambos solutos fueron superiores en el tramo no vegetado. Aunque no existen resultados concluyentes parece intuirse que estas diferencias fueron más acusadas fuera del periodo vegetativo del helófito, mientras que en los meses de primavera y verano pudiera ocurrir un incremento de las tasas de retención en los tramos vegetados. Así mismo, la capacidad de los subtramos para la retención de $N$-nitrato, mostró una clara dependencia de los aportes de nitrógeno, disminuyendo conforme la carga de nitrógeno aumenta. Sin embargo, el tramo no vegetado mostró una mayor capacidad de carga que el tramo vegetado de mayor superficie y este que el tramo vegetado de menor superficie. Este estudio pone de manifiesto que la ocupación de los cauces por Phragmites australis, fenómeno generalizado en muchas partes del mundo, no sólo puede suponer cambios en la 
estructura de la vegetación y la fauna de las ramblas sino que también afectar a su funcionamiento y muy especialmente a un proceso clave implicado en la calidad de las aguas como es la eliminación del nitrógeno.

Palabras clave: Retención de nitrógeno, ramblas, cauces intermitentes, Phragmites australis, invasión.

\section{INTRODUCTION}

In recent years, the Southeast Iberian Peninsula landscape has undergone an important modification due to an increase in irrigated lands. From 1960 to the present-day, the surface of irrigated lands has increased from 10000 ha to 17000 ha, that is, a $70 \%$ increase of land surface (Martínez \& Esteve, 2002). Moreover, the drainage of irrigated soils has brought about changes in the quality of water streams, such as a decrease in salinity and an increase in nitrogen levels due to the use of fertilizers (Ballester et al., 2003; Gómez et al., 2005), as observed in other streams around the world (e.g., Vitousek et al., 1997; Mitsch et al., 2001; Turner \& Rabalais, 2003). This situation has led to an extensive modification of the physical structure and the plant composition of wetlands and streams of the Southeast Iberian Peninsula, among other important changes (Ballester et al., 2003; Gómez et al., 2005). In the Murcia Region, the presence of temporary streams, known as "ramblas", is very common (Pulido, 1993; López Bermúdez et al., 1998; Gómez et al., 2005). Those ramblas affected by agricultural runoff present a permanent flow and, typically, Phragmites australis (Cav.) Trin.ex Steud. covers $100 \%$ of the channel area. The expansion of reeds not only generates the replacement of halophyte communities, these being the most common vegetation of the ramblas (Gómez et al., 2005), but also brings about significant changes in their structure and hydrologic conditions. In Europe, the accumulation of litter and the resulting drying-out of ground surfaces are a major conservation problem in beds of reeds (Cowie et al., 1992). Furthermore, the most important effects of reed growth in ramblas are the reduction of the surface/volume ratio of the watersheet, higher water velocity and, consequently, lower water residence time, and less light availability. The modification of these characteristics influences some of the processes involved in nitrogen retention, such as biotic assimilation, denitrification or adsorption onto sediments (De Laune et al., 1981; Howard-Williams, 1985; Reddy et al., 1989; Pinay et al., 1993; Hill, 1996; Hernandez \& Mitsch, 2007). Nitrogen (N) removal mechanisms are well documented: mineralisation, ammonium volatilisation, biotic assimilation, abiotic adsorption and nitrificationdenitrification (Reddy \& Patrick, 1984; Bernot $\&$ Dodds, 2005). Among them, the most efficient $\mathrm{N}$ removal mechanism is the coupling of nitrification and denitrification (Neely \& Baker, 1989; Reddy \& D'Angello, 1994). Plant or microbial uptake and the dissimilatory reduction of nitrate to ammonium represent $1-34 \%$ of the total $\mathrm{N}$ retention, whereas between $60-95 \%$ of $\mathrm{N}$ is removed via denitrification (Bartlett et al., 1979; Cooke, 1994). In fact, even though denitrification depends strongly on temperature, it can be active at between $4-5{ }^{\circ} \mathrm{C}$ (Sirivedhin \& Gray, 2006).

Several studies have demonstrated that smaller streams, because of their high surface/volume ratios compared with larger streams, have high processing activity in relation to their transport capacity and hence play a disproportionate role in controlling nitrogen flux from large catchments (Alexander et al., 2000; Peterson et al., 2001; Wollheim et al., 2001; Webster et al., 2003), which makes ramblas to have a high potential for nitrogen retention and removal from agricultural runoff.

Therefore, the first aim of this study was to analyse the effects of the invasion of Phragmites australis on $\mathrm{NO}_{3}^{-}-\mathrm{N}$ and $\mathrm{NH}_{4}^{+}-\mathrm{N}$ removal. We 
hypothesise that this invasion decreases the capacity for $\mathrm{N}$ removal from water as a consequence of the resulting changes in the ramblas which affect the $\mathrm{N}$ removal processes. Thus, we predict that reaches in the same stream without reeds would remove more $\mathrm{N}$ than reaches with reeds. In addition, we predict that these differences would be greater outside the vegetative period (autumnwinter) when $\mathrm{N}$ uptake by reeds is lower, and that other $\mathrm{N}$ removal processes, such as denitrification, could be active (e.g., Denny, 1987).

The second objective was to analyse the effect of the temporal variability of $\mathrm{N}$ input $\left(\mathrm{g} \mathrm{day}^{-1} \mathrm{~m}^{-2}\right)$ on stream retention rates. We hypothesise that $\mathrm{N}$ retention decreases while the $\mathrm{N}$ load increases (Howard-Williams, 1985; Kemp \& Dodds, 2001).

\section{MATERIALS AND METHODS}

The area of study, the Rambla of Ajauque, is a permanent stream located in a sedimentary basin (with marl lithology) in the most arid area of the Murcia Region, in the Southeast of the Iberian Peninsula (Fig. 1). Its climate is characterised by a mean annual precipitation below $300 \mathrm{~mm}$, and the average annual temperature is close to $18{ }^{\circ} \mathrm{C}$. The Rambla de Ajauque receives inflows from the irrigated areas around it, which are used for growing citrus and horticultural crops, and there is a tourist hot spring runoff located $5 \mathrm{~km}$ upstream. In time, this situation has led to an increase in surface flow, reduced water salinity, an increase in the nutrient levels, and to a channel invasion by $P$. australis covering $100 \%$ of the channel area. However, and as a result of the construction of a bridge over the rambla channel, vegetation has been removed from a portion of the channel. An unvegetated subreach upstream of a vegetated subreach was selected to carry out this study. The bridge construction finalised one year prior to the start of this study. Because reed invasion is extended throughout the Murcia Region, it was no possible to find more replicates of vegetated

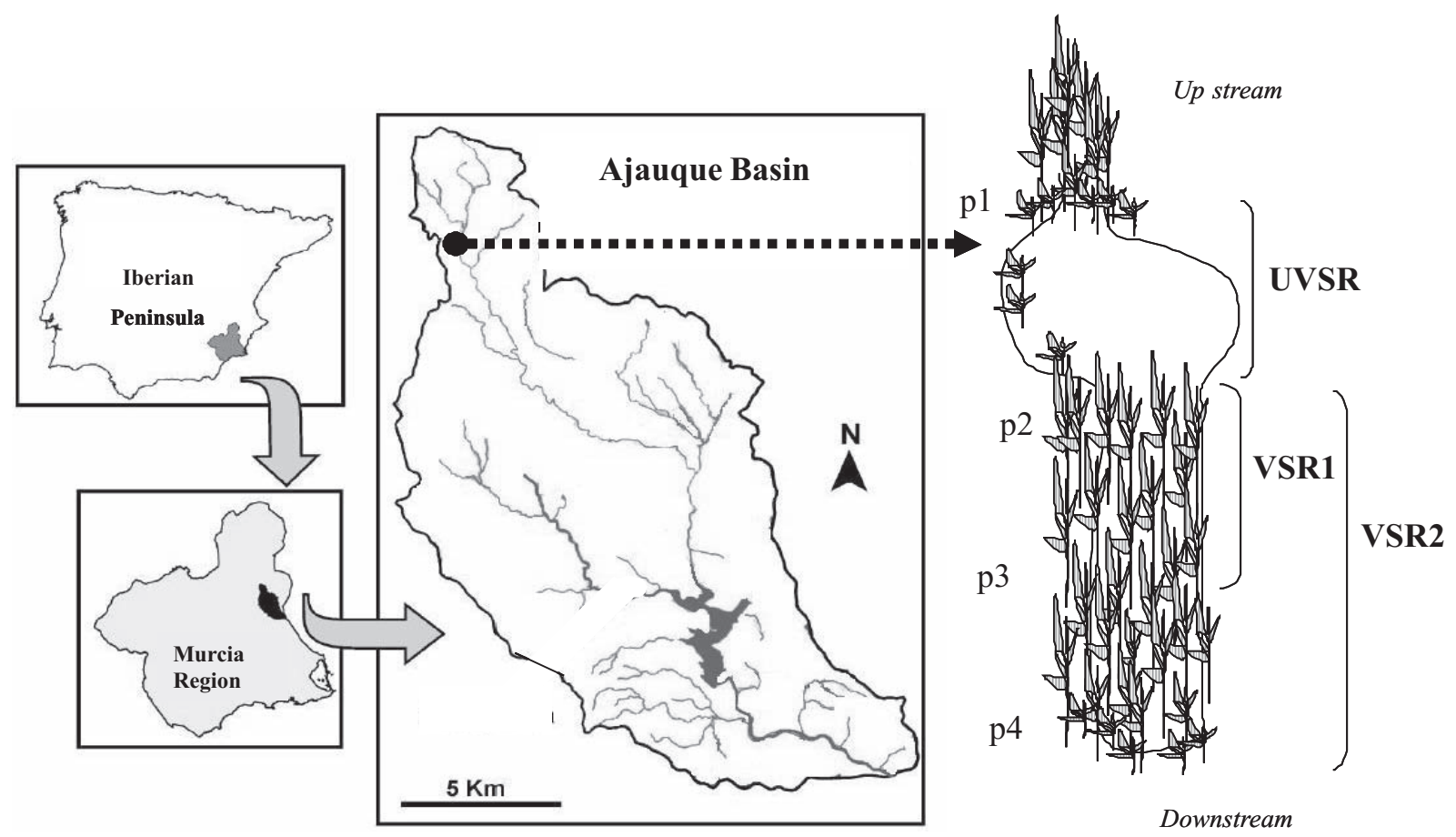

Figure 1. Location of the study area and the subreaches (UVSR = unvegetated subreach; VSR $1=$ vegetated subreach of lesser surface and VSR2 = vegetated subreach of greater surface), as well as the indication of the sampling points (p). Localización del área de estudio y de los subtramos (UVSR=subtramo sin vegetación; VSR1 = subtramo vegetado de menor superficie y VSR2 = subtramo vegetado de mayor superficie), así como de los distintos puntos de muestreo (p). 
and unvegetated reaches in the same channel, not even as far away as Rambla de Ajauque.

\section{Sample collection}

In order to test the initial hypothesis, two subreaches with a similar surface area were chosen. Both differed in terms of the presence/absence of $P$. australis (Fig. 1), and were named vegetated and unvegetated subreaches, respectively. After the first sampling event, a third vegetated subreach with a larger surface area was chosen. The unvegetated subreach (UVSR) had a surface area of $238 \mathrm{~m}^{2}$ and a reed coverage of $5 \%$ (young and small reed stems) (Table 1). The vegetated subreaches (VSR1 and VSR2) were located downstream of UVSR, and had a surface area of $480 \mathrm{~m}^{2}$ and $910 \mathrm{~m}^{2}$, respectively, and both had $100 \%$ reed coverage. The study period began in December 2006 and continued until March 2008. The sampling frequency was each other month at the beginning of the study, and avery month at the end of the study period, resulting in 15 sampling dates for UVSR, 14 for VSR1 and 6 for VSR2 (Table 1). Initially, 4 sampling points were located in the inflows and outflows of each subreach (Fig. 1). Salinity (\%o), temperature $\left({ }^{\circ} \mathrm{C}\right)$ and conductivity $(\mathrm{ms} / \mathrm{cm})$ were measured at each sampling point throughout the study with a conductivity meter (Tretacon 235, WTW, Munich, Germany). Surface water samples were collected at each sampling point with plastic syringes and were stored in previously acid-washed pol- yethylene bottles $(250 \mathrm{ml})$. Samples were stored at $4{ }^{\circ} \mathrm{C}$ and kept in the dark until analysed. The analyses were performed within $24 \mathrm{~h}$ of sample collection. Discharge was estimated as the product of the average water velocity (current meter MiniAir2, Schiltknecht Co, Zürich, Switzerland) and the cross-sectional area at the study reach inflows (inflow to UVSR, Fig. 1). The surface areas of the subreaches were delimited and calculated with a GPS (GeoXT, Trimble GeoExplorer, USA) and the ArcView GIS 3.2 software.

For the purpose of testing the possible effect of reed growth on $\mathrm{N}$ retention in the unvegetated subreach, $40 P$. australis stems were selected randomly and marked. On each sampling event $(n=15)$, the height and diameter of the stems (at a height of $15 \mathrm{~cm}$ from the ground) were recorded using a rigid metre and a vernier caliper, respectively. In addition, 4 plots of $1 \mathrm{~m}^{2}$ were delimited to estimate the growth of new $P$. australis stems over the study period, which were expressed as the number of stems $/ \mathrm{m}^{2}$.

\section{Chemical Analyses}

Water samples were analysed for nitrogen dissolved forms within 24 hours of collection. The samples were filtered through glass-fibre filters (Whatman GF/C, $1.2 \mu \mathrm{m}$ nominal pore size; Whatman International Ltd., Maidstone, England). The $\mathrm{NO}_{3}^{-}-\mathrm{N}$ concentration was measured by a colorimetric method following cadmium reduction to $\mathrm{NO}_{2}^{-}-\mathrm{N}$ (Wood et al., 1967). $\mathrm{NO}_{2}^{-}-\mathrm{N}$

Table 1. Environmental characteristics of each subreach. The width, depth, speed of current, temperature, salinity and conductivity values have been expressed as mean $\pm \mathrm{SD}$ (with $\mathbf{n}$ according to each subreach). Características ambientales de cada subtramo de estudio. Los valores de anchura profundidad, velocidad de la corriente, temperatura, salinidad y conductividad se expresan como su valor medio \pm desviación típica (con $\boldsymbol{n}$, según cada subtramo).

\begin{tabular}{lccc}
\hline & UVSR & VSR1 & VSR2 \\
\hline Sampling events (n) & 15 & 14 & 6 \\
Surface $\left(\mathrm{m}^{2}\right)$ & 238 & 480 & 910 \\
Plant coverage (\%) & 5 & 100 & 100 \\
Length reach (m) & 30 & 32 & 78.5 \\
Width reach (m) & $7.9 \pm 5$ & $15 \pm 3$ & $11.5 \pm 4$ \\
Depth water $(\mathrm{cm})$ & $3.6 \pm 2$ & $9 \pm 2$ & $8 \pm 3$ \\
Speed of current (m/s) & $0.02 \pm 0.007$ & $0.06 \pm 0.014$ & $0.06 \pm 0.025$ \\
Temperature $\left({ }^{\circ} \mathrm{C}\right)$ & $15 \pm 2$ & $9 \pm 2$ & $8 \pm 3$ \\
Salinity $(\% o)$ & $7.2 \pm 0.065$ & $6.95 \pm 0.6$ & $6.8 \pm 0.1$ \\
Conductivity $(\mathrm{ms} / \mathrm{cm})$ & $12.7 \pm 1$ & $12 \pm 2$ & $11 \pm 2$ \\
\hline
\end{tabular}


values are not presented since their concentrations in the water samples were below the detection limit. The $\mathrm{NH}_{4}^{+}-\mathrm{N}$ concentration was measured by the phenol-hypochlorite method (Solorzano, 1969). The $\mathrm{Cl}^{-}$concentration was analysed within 48 hours of collection by the silver nitrate volumetric method (APHA, 1985).

\section{Data analyses}

Chloride was used to calculate the nitrogen retention in the subreaches. As a conservative solute, $\mathrm{Cl}^{-}$underwent dispersion, dilution, and diffusion, but was not significantly removed from the solutions and, consequently, its movements largely tracked water flow. Thus, the variations in the $\mathrm{Cl}^{-}$concentration allowed the detection of the possible dilutions (by lateral water inputs) or solute concentrations (by evapotranspiration) that also affected nitrogen forms. The retention efficiency $(\% \mathrm{R})$ was calculated for the different nitrogen forms $\left(\mathrm{NO}_{3}^{-}-\mathrm{N}\right.$ and $\left.\mathrm{NH}_{4}^{+}-\mathrm{N}\right)$ on each sampling date by considering the equation used by Trudell et al. (1986):

$$
\% \mathrm{R}=\left(1-\left(\mathrm{N} / \mathrm{Cl}_{\text {out }}^{-} / \mathrm{N} / \mathrm{Cl}_{\text {in }}^{-}\right)\right) \times 100 \text {. }
$$

In this equation, $\mathrm{N} / \mathrm{Cl}_{\text {in }}^{-}$and $\mathrm{N} / \mathrm{Cl}_{\text {out }}^{-}$are the concentration ratios of both solutes in the inlet and outlet of each subreach (p1 and p2 for UVSR; p2 and $\mathrm{p} 3$ for VSR1; p2 and $\mathrm{p} 4$ for VSR2, respectively, Fig. 1). \%R is the percentage of nitrogen removed by the subreach in relation to the inflow of nitrogen. A negative retention value indicates that the outflow of the nitrogen/chloride ratio was higher than the inflow of the nitrogen/chloride ratio. The $\mathrm{N}$ inflow load (g/day) to the whole reach was calculated as the product of the $\mathrm{N}$ inflow concentration ( $\mathrm{g} / \mathrm{l})$ by the discharge (1/day) at UVSR. The \%R obtained from UVSR was applied to the $\mathrm{N}$ inflow load to the whole reach to estimate the $\mathrm{N}$ inflow load to VSR1 and to VSR2. Then, the $\mathrm{N}$ inflow loads were divided by the surface area of each subreach to calculate the $\mathrm{N}$ input $\left(\mathrm{g} \mathrm{day}^{-1} \mathrm{~m}^{-2}\right)$ for each subreach.

The $\mathrm{NO}_{3}^{-}-\mathrm{N}$ and $\mathrm{NH}_{4}^{+}-\mathrm{N}$ retention values were compared between subreaches by means of a Student's t-test. When the criterion of homocedasticity was not fulfilled, the Satterthwaite t-test was performed. The relationships between the number of stems $/ \mathrm{m}^{2}$, the diameter and length of the stems and $\mathrm{NO}_{3}^{-}-\mathrm{N}$ and $\mathrm{NH}_{4}^{+}-\mathrm{N}$ retention in UVSR were analysed by Spearman correlations. Univariate regression analyses were performed to analyse the effect of the $\mathrm{N}$ inflow load on the $\mathrm{N}$ retention in each subreach. All the statistical analyses were conducted using SPSS ${ }^{\circledR}$ for Windows, version 15.0 (SPSS, Chicago, USA). The significance level for statistical assessment was $p<0.05$.

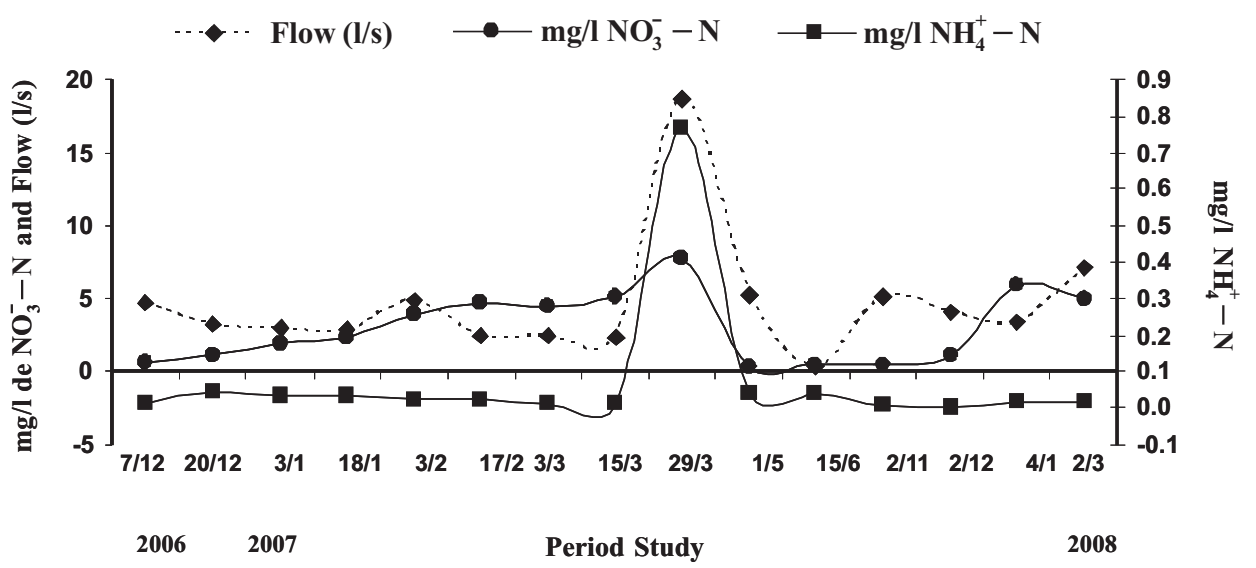

Figure 2. Temporal variation of the input $(\mathrm{mg} / \mathrm{l})$ of $\mathrm{NO}_{3}^{-}-\mathrm{N}$ (black circles) and $\mathrm{NH}_{4}^{+}-\mathrm{N}$ (black squares) concentrations and discharge (black diamonds) in the study reaches. Variación temporal de las concentraciones de $\mathrm{N}$-nitrato (círculos negros), $\mathrm{N}$-amonio (cuadros negros) y del caudal (rombos negros) a la entrada del tramo de estudio. 
Table 2. Mean value $\pm \mathrm{SD}$, and maximum and minimum values of the $\mathrm{NO}_{3}^{-}-\mathrm{N}, \mathrm{NH}_{4}^{+}-\mathrm{N}$ and $\mathrm{Cl}^{-}$concentrations (mg/l) and discharge (1/s), measured at the input (I) and output (O) of each subreach. Note that the output of UVSR is the input of VSR1 and VSR2, and that the discharge was measured only at the input of UVSR. Valor medio $\pm S D$ y valores máximos y mínimos de la concentración ( $\mathrm{mg} / \mathrm{l})$ de $\mathrm{N}-\mathrm{NO}_{3}^{-}, \mathrm{N}-\mathrm{NH}_{4}^{+}, \mathrm{Cl}^{-}$y del caudal (l/s) medidos a la entrada (I) y salida (O) de cada subtramo. Nótese que la salida del subtramo UVSR se corresponde con la entrada a los subtramos VSR1 y VSR2 y que el caudal solo se midió a la entrada del subtramo UVSR.

\begin{tabular}{|c|c|c|c|c|c|c|c|c|c|c|c|c|}
\hline & \multicolumn{3}{|c|}{ I UVSR } & \multicolumn{3}{|c|}{ O UVSR } & \multicolumn{3}{|c|}{ O VSR1 } & \multicolumn{3}{|c|}{ O VSR2 } \\
\hline & $\mathbf{X} \pm \mathrm{SD}$ & $\max$. & min. & $\mathbf{X} \pm \mathrm{SD}$ & $\max$. & $\min$. & $\mathbf{X} \pm \mathbf{S D}$ & $\max$ & $\min$. & $\mathbf{X} \pm \mathrm{SD}$ & $\max$. & $\min$. \\
\hline $\mathrm{NO}_{3}^{-}-\mathrm{N}$ & $3 \pm 2.3$ & 7.7 & 0.3 & $2.54 \pm 2.1$ & 6.7 & 0.02 & $2.77 \pm 2.1$ & 6.75 & 0.004 & $2.67 \pm 2.8$ & 6.5 & 0.000 \\
\hline $\mathrm{NH}_{4}^{+}-\mathrm{N}$ & $0.07 \pm 0.2$ & 0.7 & 0.001 & $0.064 \pm 0.2$ & 0.73 & 0.00 & $0.073 \pm 0.2$ & 0.72 & 0.000 & $0.11 \pm 0.23$ & 0.59 & 0.00 \\
\hline $\mathrm{Cl}^{-}$ & $2922 \pm 428$ & 3960 & 2177 & $2980 \pm 348$ & 3646 & 2451 & $2911 \pm 323$ & 3597 & 2404 & $2845 \pm 286$ & 3115 & 2470 \\
\hline Flow (1/s) & $4.6 \pm 4.2$ & 18.6 & 0.37 & & & & & & & & & \\
\hline
\end{tabular}

\section{RESULTS}

\section{$\mathrm{NO}_{3}^{-}-\mathrm{N}$ and $\mathrm{NH}_{4}^{+}-\mathrm{N}$ retention}

The data of the $\mathrm{NO}_{3}^{-}-\mathrm{N}, \mathrm{NH}_{4}^{+}-\mathrm{N}$ and $\mathrm{Cl}^{-}$ concentrations in the water surface and the inlet discharge in the studied reach are presented in Table 2. The $\mathrm{NO}_{3}^{-}-\mathrm{N}$ concentration was high and represents the major form of dissolved inorganic nitrogen in the water $(97 \pm 3 \%$ of DIN). The inlet discharge, and the $\mathrm{NO}_{3}^{-}-\mathrm{N}$ and $\mathrm{NH}_{4}^{+}-\mathrm{N}$ inflow concentrations, displayed high variability during the study period (Fig. 2), showing coefficients of variation $(\mathrm{CV})$ of $0.9,2.8$ and 0.76 , respectively. However, the temporal variability of the inlet $\mathrm{N}$ concentration did not relate with the inlet discharge variability (Fig. 2). Although no significant differences were observed in the inlet $\mathrm{N}$ concentrations between subreaches (Table 2) when the $\mathrm{N}$ input was calculated by $\mathrm{g} \mathrm{N}$ day $^{-1} \mathrm{~m}^{-2}$, the differences between them were higher. The $\mathrm{NO}_{3}^{-}-\mathrm{N}$ input to UVSR was 2.4-fold higher than VSR1 and 3.5-fold higher than VSR2 (Table 3). Despite the higher $\mathrm{NO}_{3}^{-}-\mathrm{N}$ input, the UVSR showed a significantly higher $\mathrm{NO}_{3}^{-}-\mathrm{N} \% \mathrm{R}(p<0.05)$ than VSR1 (Table 3$)$. In addition, VSR 1 showed $\mathrm{NO}_{3}^{-}-\mathrm{N} \% \mathrm{R}$ negative values (the outlet, represented as $\mathrm{g} \mathrm{day}^{-1} \mathrm{~m}^{-2}$, was higher than the inlet), whereas UVSR showed positive values for $\mathrm{NO}_{3}^{-}-\mathrm{N} \% \mathrm{R}$ (Fig. 3). When UVSR was compared to VSR2, no significant differences were found in $\mathrm{NO}_{3}^{-}-\mathrm{N} \% \mathrm{R}$ $(p>0.05)$. In contrast to VSR1, VSR2 did not show negative values for $\mathrm{NO}_{3}^{-}-\mathrm{N} \% \mathrm{R}$ (Fig. 3).
Regarding $\mathrm{NH}_{4}^{+}-\mathrm{N}$, the unvegetated subreach retained more $(p<0.05)$ than the vegetated subreaches (Table 3 ), and these subreaches showed negative values for $\mathrm{NH}_{4}^{+}-\mathrm{N} \% \mathrm{R}$ in most sampling events (Fig. 3). When the $\% \mathrm{R} / \mathrm{m}^{2}$ values were analysed (Table 3 ), the UVSR showed the highest efficiency in the $\mathrm{NO}_{3}^{-}-\mathrm{N}$ re-
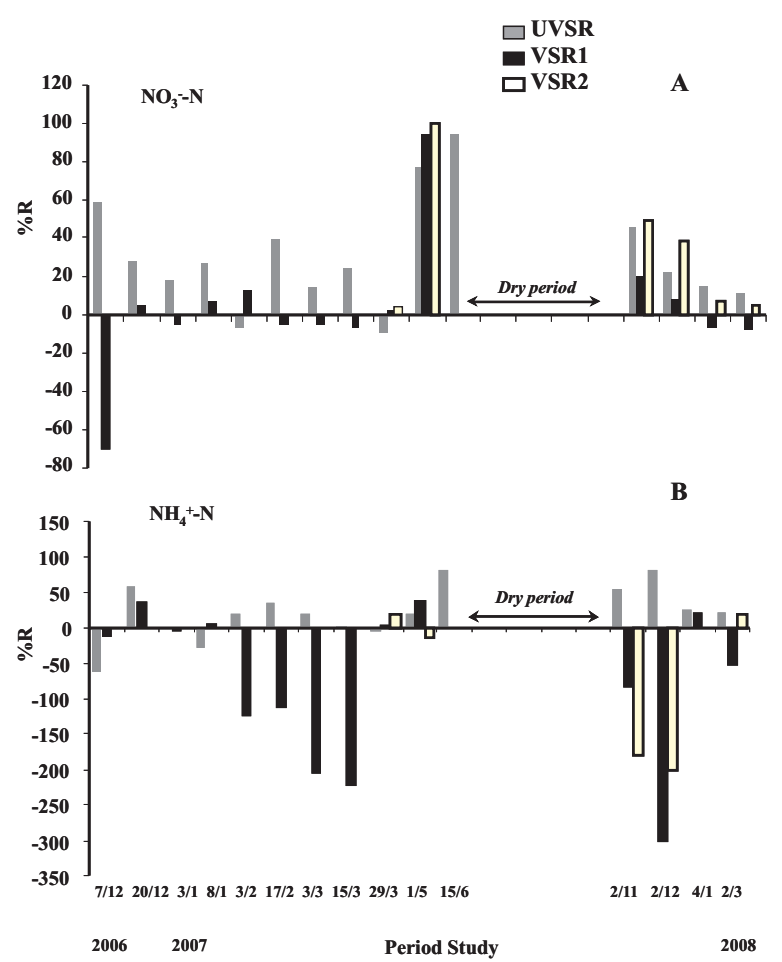

Figure 3. Temporal variation of the percentage of retention $(\% \mathrm{R})$ of $\mathrm{NO}_{3}^{-}-\mathrm{N}(\mathrm{A})$ and $\mathrm{NH}_{4}^{+}-\mathrm{N}(\mathrm{B})$ in the UVSR (grey), VSR1 (black) and VSR2 (white). Variación temporal del porcentaje de retención (\%R) de $\mathrm{N}-\mathrm{NO}_{3}^{-}$(A) y de $\mathrm{N}-\mathrm{NH}_{4}^{+}$(B) en el UVSR (gris), VSR1 (negro) y VSR2 (blanco). 
Table 3. Means values $\pm \mathrm{SD}$ of the input, output and retention $\left(\mathrm{g} \mathrm{day}^{-1} \mathrm{~m}^{-2}\right)$ and efficiency of retention $\left(\mathrm{R} \%\right.$ and $\left.\mathrm{R} \% / \mathrm{m}^{2}\right)$ in $\mathrm{NO}_{3}^{-}-\mathrm{N}$ and $\mathrm{NH}_{4}^{+}-\mathrm{N}$ in each subreach. The different letters and symbols indicate significant differences $(p<0.05)$ between the subreaches for $\mathrm{N}-\mathrm{NO}_{3}^{-}$and $\mathrm{N}-\mathrm{NH}_{4}^{+}$respectively. Valores medios $\pm S D$ de entrada, salida y retención $\left(\mathrm{g}\right.$ día $\left.{ }^{-1} m^{-2}\right)$ junto con la eficiencia de retención ( $\% \mathrm{R}$ y $\% \mathrm{R} / \mathrm{m}^{2}$ ) de $\mathrm{N}-\mathrm{NO}_{3}^{-}$y $\mathrm{N}-\mathrm{NH}_{4}^{+}$en cada subtramo. Las letras y los símbolos distintos indican diferencias significativas $(p<0.05)$ entre subtramos para el $\mathrm{N}-\mathrm{NO}_{3}^{-}$y el $\mathrm{N}-\mathrm{NH}_{4}^{+}$respectivamente.

\begin{tabular}{|c|c|c|c|c|c|c|}
\hline & \multirow[b]{2}{*}{ Subreach } & \multicolumn{3}{|c|}{ g day $^{-1} \mathrm{~m}^{-2}$} & \multirow[b]{2}{*}{$\% \mathbf{R}$} & \multirow[b]{2}{*}{$\% \mathrm{R} / \mathrm{m}^{2}$} \\
\hline & & Input & Output & Retention & & \\
\hline $\begin{array}{l}\mathrm{NO}_{3}^{-}-\mathrm{N} \\
\mathrm{NH}_{4}^{+}-\mathrm{N}\end{array}$ & UVSR & $\begin{array}{l}3.54 \pm 3.5 \\
0.37 \pm 1.3\end{array}$ & $\begin{array}{c}2.90 \pm 3.2 \\
0.36 \pm 1.33\end{array}$ & $\begin{array}{c}0.65 \pm 0.55 \\
0.005 \pm 0.01\end{array}$ & $\begin{array}{l}34 \pm 27^{a} \\
29 \pm 38^{b}\end{array}$ & $\begin{array}{l}0.14 \pm 0.11^{a} \\
0.12 \pm 0.12^{*}\end{array}$ \\
\hline $\begin{array}{l}\mathrm{NO}_{3}^{-}-\mathrm{N} \\
\mathrm{NH}_{4}^{+}-\mathrm{N}\end{array}$ & VSR1 & $\begin{array}{l}1.45 \pm 1.6 \\
0.18 \pm 0.6\end{array}$ & $\begin{array}{l}1.40 \pm 1.6 \\
0.17 \pm 0.6\end{array}$ & $\begin{array}{c}0.05 \pm 0.1 \\
0.007 \pm 0.02\end{array}$ & $\begin{array}{c}11 \pm 25^{b} \\
8 \pm 13^{\dagger}\end{array}$ & $\begin{array}{l}0.02 \pm 0.05^{b} \\
0.01 \pm 0.02^{\dagger}\end{array}$ \\
\hline $\begin{array}{l}\mathrm{NO}_{3}^{-}-\mathrm{N} \\
\mathrm{NH}_{4}^{+}-\mathrm{N}\end{array}$ & VSR2 & $\begin{array}{l}1.01 \pm 1.2 \\
0.20 \pm 0.5\end{array}$ & $\begin{array}{l}0.95 \pm 1.2 \\
0.16 \pm 0.4\end{array}$ & $\begin{array}{c}0.1 \pm 0.04 \\
0.04 \pm 0.11\end{array}$ & $\begin{array}{c}39 \pm 38^{a} \\
4 \pm 8^{\dagger}\end{array}$ & $\begin{array}{c}0.04 \pm 0.04^{b} \\
0.004 \pm 0.01^{\dagger}\end{array}$ \\
\hline
\end{tabular}

tention $(p<0.05)$, followed by VSR2 and finally by VSR1. In the same way, the $\mathrm{NH}_{4}^{+}-\mathrm{N}$ retention in UVSR was higher than the retention observed in the vegetated subreaches $(p<0.05)$. Although no statistical differences were found in the $\% \mathrm{R} / \mathrm{m}^{2}$ values between both vegetated subreaches $(p=0.10)$, VSR1 was more efficient than VSR2 in terms of $\mathrm{NH}_{4}^{+}-\mathrm{N}$ retention.

\section{Temporal variability of $\mathrm{N}$ retention and involved factors}

The temporal variability of $\mathrm{NO}_{3}^{-}-\mathrm{N}$ and $\mathrm{NH}_{4}^{+}-\mathrm{N}$ $\% \mathrm{R}$ was high during the period of study (Fig. 3), with coefficients of variation for UVSR, VSR1 and VSR2 of 0.79, 2.29 and 0.97, respectively, in the case of $\mathrm{NO}_{3}^{-}-\mathrm{N}$, and $0.97,1.86$ and 2.24, respectively for $\mathrm{NH}_{4}^{+}-\mathrm{N} \% \mathrm{R}$.

The highest $\mathrm{NO}_{3}^{-}-\mathrm{N} \% \mathrm{R}$ for the three subreaches was observed in May. Exceptionally at this time, the \%R of VSR1 was higher than that of UVSR (Fig. 3). From May to November, the $\% \mathrm{R}$ there was not data due to the drought situation to which the vegetated subreaches were subjected. In contrast, the unvegetated subreach underwent drought later, specifically in the second half of June, after the maximum $\mathrm{NO}_{3}^{-}-\mathrm{N} \% \mathrm{R}$ was observed $(95 \%)$. No clear seasonal pattern was seen in relation to the variation of the differences of $\mathrm{NO}_{3}^{-}-\mathrm{N} \% \mathrm{R}$ between UVSR and VSR1 (Fig. 3). Nevertheless, the $\mathrm{NO}_{3}^{-}-\mathrm{N}$ retention in VSR1 increased in May and its \% $\mathrm{R}$ va- lue $(94 \%)$ was even higher than that of UVSR $(77 \%)$. A seasonal pattern was neither detected for $\mathrm{NH}_{4}^{+}-\mathrm{N} \% \mathrm{R}$ with the vegetated subreaches and showed negative $\% \mathrm{R}$ values on many sampling dates throughout winter (Fig. 3). This fact stresses the differences with the unvegetated subreach, mainly in the winter months. Nevertheless in spring (March and May), the retention of $\mathrm{NH}_{4}^{+}-\mathrm{N}$ in the vegetated subreaches was higher, while the differences with the unvegetated subreach were lower. Indeed at the end of March, the $\mathrm{NH}_{4}^{+}-\mathrm{N}$ retentions in VSR1 (4\%) and VSR2 (20\%) were higher than in UVSR $(-3 \%)$, and the $\% \mathrm{R}$ in VSR1 in May exceeded (38\%) that of UVSR $(19 \%)$, whereas VSR2 exported $\mathrm{NH}_{4}^{+}-\mathrm{N}(-2 \%)$.

Spearman correlations were performed to evaluate the relationship between the $\mathrm{NO}_{3}^{-}-\mathrm{N}$ and $\mathrm{NH}_{4}^{+}-\mathrm{N} \% \mathrm{R}$ values in the UVSR, and the reed growth variables (diameter and length of stems, and number of stems $/ \mathrm{m}^{2}$ ) (Table 4) revealed no relationship between them. However, the relationship between the variables used to study reed growth was positive (diameter and length of stems, and number of stems $\left./ \mathrm{m}^{2}\right)$.

Regarding the second objective of testing for the effect of $\mathrm{N}$ inflow load variability $\left(\mathrm{g} \mathrm{day}^{-1} \mathrm{~m}^{-2}\right)$ on $\mathrm{N}$ retention efficiency, the regression analyses (Fig. 4) were only significant for $\mathrm{NO}_{3}^{-}-\mathrm{N}$, whereas a non-significant regression was obtained for $\mathrm{NH}_{4}^{+}-\mathrm{N}$. A negative relationship between the $\mathrm{NO}_{3}^{-}-\mathrm{N}$ inputs $\left(\mathrm{g}_{\text {day }}{ }^{-1} \mathrm{~m}^{-2}\right)$ and $\mathrm{NO}_{3}^{-}-\mathrm{N} \% \mathrm{R}$ values was observed for all the 


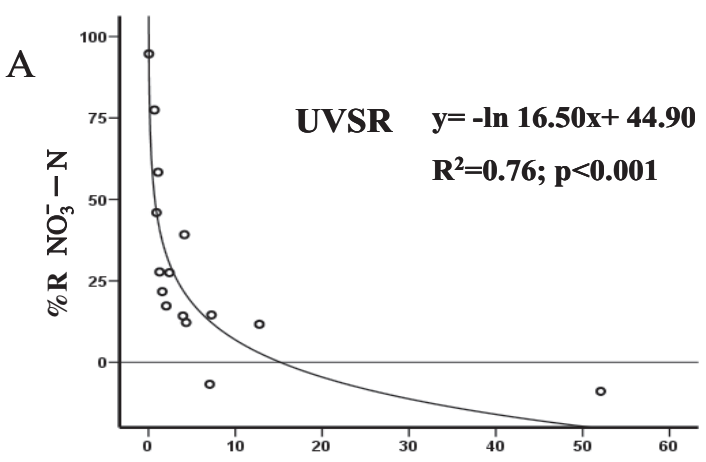

B
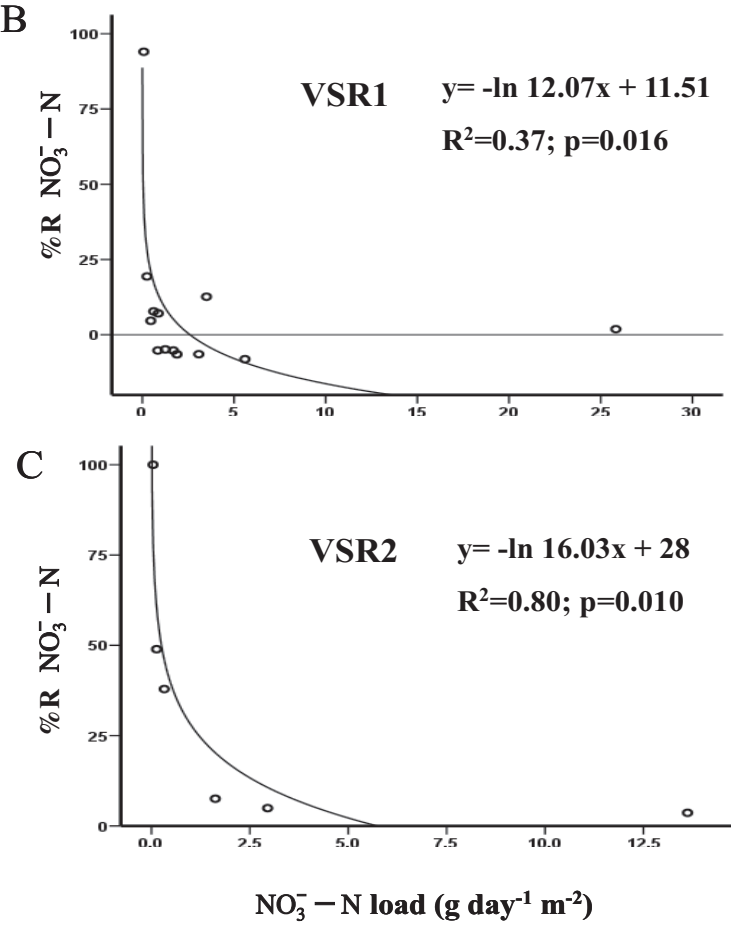

Figure 4. Logarithmic regression (best fit) between $\mathrm{NO}_{3}^{-}-\mathrm{N}$ load $\left(\mathrm{g} \mathrm{day}^{-1} \mathrm{~m}^{-2}\right)$ and percentage of retention (\%R) for each subreach: UVSR (A), VSR1 (B) and VSR2 (C). Regresión logarítmica (mejor ajuste) entre los aportes de $\mathrm{N}-\mathrm{NO}_{3}^{-}$ ( $g$ día ${ }^{-1} \mathrm{~m}^{-2}$ ) y el porcentaje de retención (\%R) para cada $\mathrm{sub}$ tramo: UVSR (A), VSR1 (B) y VSR2 (C).

subreaches (Fig. 4). The retention of $\mathrm{NO}_{3}^{-}-\mathrm{N}$ decreased in the three subreaches when the $\mathrm{NO}_{3}^{-}-\mathrm{N}$ input increased, which fitted a logarithmic model (Fig. 4). The fit was greater for UVSR and VSR2, with a higher level of significance than that observed for VSR1. Besides, the model showed a threshold value in the $\mathrm{NO}_{3}^{-}-\mathrm{N}$ input for which the retention was null and even negative. Therefore, a maximum $\mathrm{NO}_{3}^{-}-\mathrm{N}$ load was detected in each
Table 4. Values of the Spearman correlation analyses between the reed growth variables at UVSR and the retention percentages of $\mathrm{NO}_{3}^{-}-\mathrm{N}$ and $\mathrm{NH}_{4}^{+}-\mathrm{N}$ at UVSR. Asterisks indicate significant correlation $(* * p<0.01)$. Valores del análisis de correlación de Spearman entre las variables de crecimiento de carrizo en UVSR y los porcentajes de retención de $\mathrm{N}-\mathrm{NO}_{3}^{-}$y $\mathrm{N}-\mathrm{NH}_{4}^{+}$en UVSR Los asteriscos indican correlación significativa $(* * p<0.01)$.

\begin{tabular}{lccc}
\hline \multicolumn{4}{c}{ P. australis growth and \%R of N UVSR } \\
\hline & $\begin{array}{c}\text { Diameter } \\
\text { stem }\end{array}$ & $\begin{array}{c}\text { Heigth } \\
\text { stem }\end{array}$ & $\begin{array}{c}\text { Number } \\
\text { stems } / \mathbf{m}^{2}\end{array}$ \\
\hline Diameter stem & & $0.85^{*} *$ & $0.82^{*} *$ \\
Height stem & & & $0.97^{*} *$ \\
$\% \mathrm{R} \mathrm{NO}_{3}^{-}-\mathrm{N}$ UVSR & -0.31 & -0.19 & 0.08 \\
$\% \mathrm{R} \mathrm{NH}_{4}^{-}-\mathrm{N}$ UVSR & 0.11 & 0.23 & 0.38 \\
\hline
\end{tabular}

subreach from which the subreaches were unable to retain $\mathrm{N}$ and started to export it. This pattern was observed mainly in the regression model for VSR1 where negative values of $\% \mathrm{R}$ were found, indicating $\mathrm{NO}_{3}^{-}-\mathrm{N}$ exportation. The analysis of these regression models (Fig. 4) reveals that the threshold value between subreaches differs and that the UVSR subreach shows a higher load capacity for $\mathrm{NO}_{3}^{-}-\mathrm{N}$ than for VSR1 and VSR2.

\section{DISCUSSION}

\section{Effect of the expansion of $P$. australis on $\mathrm{NO}_{3}^{-}-\mathrm{N}$ and $\mathrm{NH}_{4}^{+}-\mathrm{N}$ retention}

The differences shown for the $\mathrm{N}$ retention $\left(\% \mathrm{R} / \mathrm{m}^{2}\right)$ between subreaches support our initial hypothesis that a massive invasion of $P$. australis in stream channels has negative effects on $\mathrm{N}$ retention. We suspect that the physical and hydrological changes that reed growth brings about, alter some of the processes involved in net $\mathrm{N}$ retention, such as denitrification or adsorption onto sediments (De Laune et al., 1981; Howard-Williams, 1985; Bowden, 1987; Reddy et al., 1989; Pinay et al., 1993; Hill, 1996; Bernot \& Dodds, 2005), thus leading to a decrease in $\mathrm{N}$ retention. In accordance with the results of $\mathrm{NO}_{3}^{-}-\mathrm{N} \% \mathrm{R}$, the unvegetated subreach $\left(238 \mathrm{~m}^{2}\right)$ is the most efficient of the three subreaches of this study. However when $P$. australis is present (VSR2), it is necessary to increase the surface area 4 -fold $\left(910 \mathrm{~m}^{2}\right)$ 
to obtain a similar \%R. As for the results obtained for reed growth, although we observed a moderate growth in the unvegetated subreach, it was not sufficient to influence its \% R. The lack of correlation between this last variable and those used to estimate the growth of $P$. australis confirm this hypothesis.

Despite the presence of reeds in the streams possibly playing an important role in $\mathrm{N}$ assimilation, we believe that other biotic (microbial assimilation and desnitrification) and abiotic (adsorption onto sediments) processes may prove more important in N removal given the ramblas' characteristics. Several authors have reported that denitrification may be potentially more important than plant uptake in aquatic ecosystems under specific conditions, such as low redox potential of sediments, fine substrate, high $\mathrm{NO}_{3}^{-}-\mathrm{N}$ content and organic carbon availability (Kaplan \& Valiela, 1979; Reddy et al., 1980; De Laune et al., 1998; Clément et al., 2003; Toet et al., 2003). Although we did not evaluate denitrification in this study, we suspect that this process may be an important pathway for $\mathrm{NO}_{3}^{-}-\mathrm{N}$ loss in the unvegetated subreach given its environmental characteristics. Moreover, variables like a larger surface/volume ratio, higher water residence time and a higher insolation in the unvegetated subreach have a positive effect on the biotic and abiotic processes implicated in $\mathrm{N}$ retention if compared to the vegetated subreaches (e.g., Howard-Williams, 1985).

Although we must be careful when interpreting the results obtained in this study given the absence of a second study area, our results suggest that the loss of heterogeneity in streams, and consequently the loss of diversity in biogeochemical processes, negatively affects $\mathrm{N}$ removal. The same idea, based on the different environmental conditions required by $\mathrm{N}$ retention processes, has been suggested by other authors (e.g., Kemp \& Dodds, 2001; McClain et al., 2003).

Detritus accumulation in the stream bed not only alters the structure and hydrological conditions of streams, but could also be a source of nitrogen. This idea is another important factor to understand our results. The nitrogen net retention could lower due to detritus accumulation (when reed leaves decay), organic matter decomposi- tion, and the release of $\mathrm{NH}_{4}^{+}-\mathrm{N}$ and $\mathrm{NO}_{3}^{-}-\mathrm{N}$ into systems. Several research works have demonstrated that detritus decomposition in systems where these nutrients are not limited could enrich the nutrient level of streams (e.g., Howarth \& Fisher, 1976; MacLean \& Wein, 1978). In a study conducted in small artificial wetlands, Braskerud (2002) explained the loss in retention efficiency through detritus accumulation. Indeed in Europe, a number of studies have recently evaluated the effect of reeds on $\mathrm{N}$ availability in wetlands by considering them a strong nutrient releaser (Lippert et al., 1999; Picek et al., 2000).

This hypothesis could also explain not only the differences in $\mathrm{N}$ retention between the subreaches, but also the low efficiency of the vegetated subreaches. We hypothesize that the $\mathrm{N}$ export processes in the vegetated reaches are greater than the $\mathrm{N}$ retention processes, and that they result in a negative net retention balance. The low $\mathrm{N}$-ammonium retention in the vegetated subreaches (mainly in VSR2) supports our hypothesis. The stream invasion by Phragmites could contribute to water and sediment oxygenation. This situation could increase the mineralisation and nitrification processes over denitrification, as demonstrated in several wetland research works (Reddy et al., 1989).

With the exception of denitrification, the $\mathrm{NO}_{3}^{-}-\mathrm{N}$ uptake by plants is considered one of the main mechanisms of $\mathrm{N}$ removal, although this is a short term retention (temporal retention). During the non-vegetative period, plant uptake decreases, and both the translocation of nutrients from stems to rhizomes and the decomposition of tissues also take place, thus increasing the nutrient concentrations in the water column (Peverly, 1985; Denny, 1987; Ruiz, 2006).

To explain the short efficiency in the $\mathrm{NH}_{4}^{+}-\mathrm{N}$ retention, in addition to detritus mineralization and the consistent export of nutrients, we have to consider that ammonium is the more unstable $\mathrm{N}$ form that changes according to the environmental conditions such as the redox state of the sediments (Buturini \& Sabater, 2002; Gücker \& Boëchat, 2004). Slight physical and chemical changes in sediments can lead to their adsorption or release into the system. 
Regarding our second prediction, finding a clear seasonal pattern in the differences in retention between subreaches proved difficult. Initially, we expected the differences in the $\% \mathrm{R}$ values between the unvegetated and vegetated subreaches to be higher outside the vegetative period (autumn-winter) when plant uptake is low. Nonetheless, the remaining nitrogen removal processes remained active. As expected, we observed retention in the unvegetated subreach in autumn and winter, whereas the \% $\mathrm{R}$ in the vegetated subreach (VSR1) was very low, and even negative. The increase in the $\% \mathrm{R}$ of the vegetated subreaches in May (spring) could mean an activation of the assimilation process by plants. However, the absence of data in spring-summer, given the absence of water in the stream, did not allow us to test this prediction.

\section{The factors involved in nitrogen retention}

In the subreaches studied, $\mathrm{NO}_{3}^{-}-\mathrm{N}$ retention decreased while $\mathrm{NO}_{3}^{-}-\mathrm{N}$ load increased which followed a logarithmic model and showing a threshold value for $\mathrm{NO}_{3}^{-}-\mathrm{N}$ input. Over this threshold value, the subreaches began to export. However, this value differed between subreaches. Similar responses in relation to $\mathrm{N}$ retention have been found in natural and artificial wetlands (e.g., Cooke, 1994; Spieles \& Mitsch, 2000).

The N retention observed in the vegetated subreaches indicates a clear effect of the surface area occupied by reeds on retention efficiencies. In this way, the different loading capacity of the vegetated subreaches; $\% \mathrm{R} / \mathrm{m}^{2}=0.02 \% / \mathrm{m}^{2}$ and $0.04 \% / \mathrm{m}^{2}$ for VSR1 $\left(480 \mathrm{~m}^{2}\right)$ and VSR2 $\left(910 \mathrm{~m}^{2}\right)$, respectively, suggested that a minimum surface area of stream channel is required for a positive net $\mathrm{N}$ retention (i.e., retention processes overtake decomposition and releasing processes). In fact, the high frequency of the $\mathrm{NO}_{3}^{-}-\mathrm{N}$ and $\mathrm{NH}_{4}^{+}-\mathrm{N}$ releasing events in the vegetated subreach with a smaller surface area compared to the vegetated subreach with a larger surface area supports our hypothesis. Furthermore, a 2-fold increase in the surface area of the vegetated subreach (VSR1 vs. VSR2) did not duplicate the $\% \mathrm{R}$ value as expected; instead it increased 4 -fold.
It is well-known that the main factor causing the changes in the structure of vegetation in wetlands is the variability in the water level, followed by an increase in nutrients load (e.g., HowardWilliams, 1985; van der Valk, 1987). In the Southeast Iberian Peninsula, streams receive water inputs from agriculture because of the increase of irrigated lands which, in turn, decreases natural water salinity and increases water nutrient levels. This situation is one of the most optimum for an expansion of Phragmites in wetlands and streams (e.g., Burdick et al., 2001), a situation which has presently discontinued, partly due to the high natural salinity of some of these systems in the Province of Murcia. The phenomenon of antropic activities enabling an invasion of Phragmites australis, which affects the presence of other plant species, has been analysed in several studies that describe how to stop such expansion (Cowie et al., 1992; Benoit \& Askins, 1999; Chambers et al., 1999; Bart \& Hartman, 2002). In general, these studies show that the invasion of Phragmites causes the loss of not only plant communities, but also animal communities, especially some bird species (Cowie et al., 1992; Benoit \& Askins, 1999). However, fewer studies have been conducted on how the invasion of reed affects the function of aquatic systems (e.g., Marks et al., 1994, Chambers et al., 1999). Therefore, although the results obtained in this report are limited to one study case, they represent the first data on the effect of Phragmites on $\mathrm{N}$ retention in ramblas mediated by changes in plant structure and hydrological conditions. We conclude that this study emphasises the importance of further research on this topic in order to obtain applicable results for the appropriate management of ramblas in agricultural catchments.

\section{ACKNOWLEDGEMENTS}

We would like to thank Nazaret González and Antonio García-Lacunza for their help in this study. We also wish to thank Antonio Rocamora for the information about the study area.

This research was supported by project CGL2006-08134 from the Spanish Ministry of Edu- 
cation and Science (2006-09), and by R-238/2006 project from the General Authorities of the Spanish Ministry of the Environment (2005-07). Finally, the authors would like to thank the two anonymous reviewers for their comments which have greatly contributed to the improvement of this paper.

\section{REFERENCES}

ALEXANDER, R. B., R. A. SMITH \& G. E. SCHWARTZ. 2000. Effect of stream channel size on the delivery of nitrogen to the Gulf of Mexico. $\mathrm{Na}$ ture, 403: 758-761.

APHA-AWWA-WPCF. 1985. Standard methods for the examination of water and wastewater, 16 th ed. Washington. 769 pp.

BALLESTER, R., M. R. VIDAL-ABARCA, M. A. ESTÉVE \& M. L. SUÁREZ. 2003. Los humedales de la Región de Murcia (Humedales y Ramblas). Consejería de Agricultura, Agua y Medio Ambiente de la Comunidad Autónoma de la Región de Murcia. 137 pp.

BART, D. \& J. M. HARTMAN. 2002. Environmental constraints on early establishment of Phragmites australis in salt marshes. Wetlands, 22: 201-213.

BARTLETT, M. S., L. C. BROWN, N. B. HANES \& N. H. NICKERSON. 1979. Denitrification in freshwater wetlands soil. J. Environ. Qual., 8: 460464.

BENOIT, L. K. \& R. A. ASKINS. 1999. Impact of the spread of Phragmites on the distribution of birds in Connecticut tidal marshes. Wetlands, 19: 194-208.

BERNOT, M. J. \& W. K. DODDS. 2005. Nitrogen retention, removal, and saturation in lotic ecosystems. Ecosystems, 8: 442-453.

BOWDEN, W. B. 1987. The biogeochemistry of nitrogen in freshwater wetlands. Biogeochemistry, 4: 313-348.

BRASKERUD, B. C. 2002. Factors affecting nitrogen retention in small constructed wetlands treating agricultural non-point source pollution. Ecol. Eng., 18: 351-370.

BURDICK, D. M., R. BUCHSBAUM \& E. HOLT. 2001. Variation in soil salinity associated with expansion of Phragmites australis in salt marshes. Environ. Exp. Bot., 46: 247-261.

BUTURINI, A. \& F. SABATER. 2002. Nitrogen concentrations in a small Mediterranean stream: 1.
Nitrate 2. Ammonium. Hydrol. Earth Syst. Sci., 6: 539-550.

CHAMBERS, R. M., L. MEYERSON \& K. SALTONSTALL. 1999. Expansion of Phragmites australis into tidal wetlands of North America. Aquat. Bot., 64: 261-273.

CLÉMENT, J. C., R. M. HOLMES, B. J. PETERSON \& G. PINAY. 2003. Isotopic investigation of denitrification in a riparian ecosystem in western France. J. Appl. Ecol., 40: 1035-1048.

COOKE, J. G. 1994. Nutrient transformations in a natural wetland receiving sewage effluent and the implications for waste treatment. Water Sci. Technol., 29: 209-217.

COWIE, N. R., W. J. SUTHERLAND, M. K. M. DITLHOGO \& R. JAMES. 1992. The effects of conservation management of reed beds. II. The flora and litter disappearance. J. Appl. Ecol., 29: 277284.

DE LAUNE, R. D., C. N. REDDY \& W. H. PATRICK. 1981. Effect of $\mathrm{pH}$ and redox potential on concentration of dissolved nutrients in an estuarine sediment. J. Environ. Qual., 10: 276-279.

DE LAUNE, R. D., C. W. LINDAU, E. SULAEMAN \& A. JUGSUJINDA. 1998. Nitrification and denitrification estimates in a Louisiana swamp forest soil as assessed by ${ }^{15} \mathrm{~N}$ isotope dilution and direct gaseous measurements. Water Air Soil Poll., 106: 149-161.

DENNY, P. 1987. Mineral cycling by wetland plantsa review. Arch. Hydrobiol. Beih., 27: 1-25.

GÓMEZ, R., I. HURTADO, M. L. SUÁREZ \& M. R. VIDAL-ABARCA. 2005. Ramblas in south-east Spain: threatened and valuable ecosystems. Aquat. Conserv., 15: 387-402.

GÜCKER, B. \& I. G. BOECHAT. 2004. Stream morphology controls ammonium retention in tropical headwaters. Ecology, 85: 2818-2827.

HERNÁNDEZ, E. M. \& M. J. MITSCH. 2007. Denitrification in created riverine wetlands: influence of hydrology and season. Ecol. Eng., 30: 78-88.

HILL, A. R. 1996. Nitrate removal in stream riparian zones. J. Environ. Qual., 25: 743-755.

HOWARD-WILLIAMS, C. 1985. Cycling and retention of nitrogen and phosphorus in wetlands a theoretical and applied perspective. Freshwater Biol., 15: 391-431.

HOWARTH, R. W. \& S. G. FISHER. 1976. Carbon, nitrogen, and phosphorus dynamics during leaf decay in nutrient-enriched stream micro-ecosystems. Freshwater Biol., 6: 221-228. 
KAPLAN, W. \& I. VALIELA. 1979. Denitrification in a salt marsh ecosystem. Limnol. Oceanogr., 24: 726-734.

KEMP, M. J. \& W. K. DODDS. 2001. Spatial and temporal patterns of nitrogen in prairie streams. Biogeochemistry, 53: 125-141.

LIPPERT, I., H. ROLLETSCHEK, H. KUHL \& J. G. KOHL.1999. Internal and external nutrient cycles in strands of Phragmites australis-a model for two ecotypes. Hydrobiologia, 408: 343-348.

LÓPEZ BERMÚDEZ, F., C. CONCESA \& F. ALONSO. 1998. Ramblas y barrancos mediterráneos: medio natural y respuesta humana. Mediterráneo, 12-13: 223-242.

McCLEAN, D. A. \& R. W. WEIN. 1978. Weight loss and nutrient changes in decomposing litter and forest floor material in New Brunswick forest stand. Can. J. Botany, 56: 2730-2749.

McCLAIN, M. E., E. W. BOYER, C. L. DENT, S. E. GERGEL, N. B. GRIMM, P. M. GROFFMAN, S. C. HART, J. W. HARVEY, C. A. JOHNSTON, E. MAYORGA, W. H. MCDOWELL \& G. PINAY. 2003. Biogeochemical hot spots and hot moments at the interface of terrestrial and aquatic ecosystems. Ecosystems, 6: 301-312.

MARKS, M., B. LAPIN \& J. RANDALL. 1994. Phragmites australis (Phragmites communis): threats, management, and monitoring. Nat. Areas J., 14: 285-194.

MARTÍNEZ FERNANDEZ, J. y M. A. ESTEVE SELMA. 2002. Agua y regadío en la cuenca del Segura: una espiral de insostenibilidad. En: Agua, regadio y sostenibilidad en el Sudeste ibérico. J. Martínez Fernández y M. A. Estéve Selma (eds.): 23-49. Bakeaz, Bilbao, España.

MITSCH, W. J., J. W. DAY, W. J. WILLIAM, P. M. GROFFMAN, D. L. HEY, G. W. RANDALL \& N. WANG. 2001. Reducing nitrogen loading to the Gulf of Mexico from the Mississippi River Basin: strategies to counter a persistent ecological problem. BioScience, 51: 373-388.

NEELY, R. K. \& J. L. BAKER. 1989. Nitrogen and phosphorus dynamics and the fate of agricultura runoff. In: Northern Prairie Wetlands. A. G. Van der Valk (ed.): 92-131. Iowa State University Press, IA, USA.

PETERSON, B. J., W. H. WOLLHEIM, P. J. MOLHOLLAND, J. R. WEBSTER, J. L. MEYER, J. L. TANK, E. MARTÍ, W. B. BOWDEN, H. M. VALETT, A. E. HERSHEY, W. H. MCDOWELL, W. K. DODDS, S. K. M. HAMILTON, S. GREGORY
\& D. J. MORRALL. 2001. Control of nitrogen export from watersheds by headwater streams. Science, 292: 68-90.

PEVERLY, J. H. 1985. Element accumulation and release by macrophytes in a wetland stream. J. Environ. Qual., 14: 137-143.

PICEK, T., F. LUSBY, H. CIZKOVA, H. SANTRUCKOVA, M. SIMEK, J. KVET \& L. PECHAR. 2000. Microbial activities in soils of a healthy and a declining reed stand. Hydrobiologia, 418: 45-55.

PINAY, G., L. ROQUES \& A. FABRE. 1993. Spatial and temporal patterns of denitrification in a riparian forest. J. Appl. Ecol., 30: 581-591.

PULIDO, A. 1993. Las ramblas mediterráneas: condicionantes geomorfológicos e hidrológicos. Las ramblas mediterráneas. Actas de la VI Aula de Ecología, Institutos de Estudios Almerienses, Diputación de Almería, Almería: 135-144.

REDDY, K. R. \& E. M. D’ANGELLO. 1994. Soil processes regulating water quality in wetlands. In: Global Wetlands: Old World and New. W. J. Mitsch (ed.): 309-324. Elsevier, Amsterdam, The Netherlands.

REDDY, K. R. \& W. H. PATRICK. 1984. Nitrogen transformations and loss in flooded soils and sediments. CRC Crit. Rev. Environ. Control, 13: 273309.

REDDY, K. R., W. H. PATRICK \& R. E. PHILLIPS. 1980. Evaluation of selected processes controlling nitrogen loss in a flooded soil. Soil Sci. Soc. Am. J., 44: 1241-1246.

REDDY, K. R., W. H. PATRICK \& C. W. LINDAU. 1989. Nitrification-denitrification at the plant rootsediment interface in wetlands. Limnol. Oceanogr., 34: 1004-1013.

RUIZ MARTÍNEZ, M. D. M. 2006. Bioacumulación de nutrientes en Phragmites australis en la rambla del Albujón. Elemento de gestión para la reducción de la contaminación del Mar Menor. Tesis de Licenciatura, Universidad de Murcia. 78 pp.

SIRIVEDHIN, T. \& K. A. GRAY. 2006. Factors affecting denitrification rates in experimental wetlands: field and laboratory studies. Ecol. Eng., 26: 167-181.

SOLORANZO, L. 1969. Determination of ammonia in natural waters by the phenolhypochlorite method. Limnol. Oceanogr., 14: 799-801.

SPIELES, D. J. \& W. J. MITSCH. 2000. The effects of season and hydrologic and chemical loading on 
nitrate retention in constructed wetlands: a comparison of low- and high-nutrient riverine systems. Ecol. Eng., 14: 77-91.

TOET, S., L. H. F. A. HUIBERS, R. S. P. VAN LOGTESTIJN \& J. T. A. VERHOEVEN. 2003. Denitrification in the periphyton associated with plant shoots and in the sediment of a wetland system supplied with sewage treatment plant effluent. $H y$ drobiologia, 501: 29-44.

TRUDELL, M. R., R. W. GILLHAM \& J. A. CHERRY. 1986. An in-situ study of the occurrence and rate of denitrification in a shallow unconfined sand aquifer. J. Hydrol., 83: 251-268.

TURNER, R. E. \& N. N. RABALAIS. 2003. Linking landscape and water quality in the Mississippi River Basin for 200 years. BioScience, 53: 563-572.

VAN DER VALK, A. G. 1987. Vegetation dynamics of freshwater wetlands: A selective review of the literature. Arch. Hydrobiol. Beih., 27: 27-39.

VITOUSEK, P. M., J. D. ABER, R. W. HOWARTH, G. E. LIKENS, P. A. MATSON, D. W. SCHINDLER, W. H. SCHLESINGER \& D. G. TILMANET. 1997.
Human alteration of the global nitrogen cycle: sources and consequences. Ecol. Appl., 7: 737-750. WEBSTER, J. R., P. J. MULHOLLAND, J. L. TANK, H. M. VALETT, W. K. DODDS, B. J. PETERSON, W. B. BOWDEN, C. N. DAHM, S. FINDLAY, S. V. GREGORY, N. B. GRIMM, S. K. HAMILTON, S. L. JOHNSON, E. MARTÍ, W. H. MCDOWELL, J. L. MEYER, D. D. MORRALL, S. A. THOMAS \& W. M. WOLLHEIM. 2003. Factors affecting ammonium uptake in streams-an interbiome perspective. Freshwater Biol., 48: 1329-1352.

WOLLHEIM, W. M., B. J. PETERSON, L. A. DEEGAN, J. E. HOBBIE, B. HOOKER, W. B. BOWDEN, K. J. EDWARSON, D. B. ARSCOTT \& A. E. HERSHEY. 2001. Influence of stream size on ammonium and suspended particulate nitrogen processing. Limnol. Oceanogr., 46: 1-13.

WOOD, E. D., F. A. ARMSTRONG \& F. A. RICHARDS. 1967. Determination of nitrate in seawater by cadmium-copper reduction to nitrate. $J$. Mar. Biol. Assoc., 47: 23-31. 